\title{
Self-assembly of flower-like LaNiAIO3-supported nickel catalysts for CO methanation
}

Arandiyan, Hamidreza; Kasaeian, Ghasem; Nematollahi, Behzad; Wang, Yuan; Sun, Hongyu; Bartlett, Stuart; Dai, Hongxing; Rezaei, Mehran

Published in:

Catalysis Communications

Link to article, DOI:

10.1016/j.catcom.2018.07.001

Publication date:

2018

Document Version

Peer reviewed version

Link back to DTU Orbit

Citation (APA):

Arandiyan, H., Kasaeian, G., Nematollahi, B., Wang, Y., Sun, H., Bartlett, S., Dai, H., \& Rezaei, M. (2018). Selfassembly of flower-like LaNiAlO -supported nickel catalysts for $\mathrm{CO}$ methanation. Catalysis Communications, 115, 40-44. https://doi.org/10.1096/j.catcom.2018.07.001

\section{General rights}

Copyright and moral rights for the publications made accessible in the public portal are retained by the authors and/or other copyright owners and it is a condition of accessing publications that users recognise and abide by the legal requirements associated with these rights.

- Users may download and print one copy of any publication from the public portal for the purpose of private study or research.

- You may not further distribute the material or use it for any profit-making activity or commercial gain

- You may freely distribute the URL identifying the publication in the public portal 


\section{Accepted Manuscript}

Self-assembly of flower-like LaNiAlO3-supported nickel catalysts for $\mathrm{CO}$ methanation

Hamidreza Arandiyan, Ghasem Kasaeian, Behzad Nematollahi, Yuan Wang, Hongyu Sun, Stuart Bartlett, Hongxing Dai, Mehran Rezaei

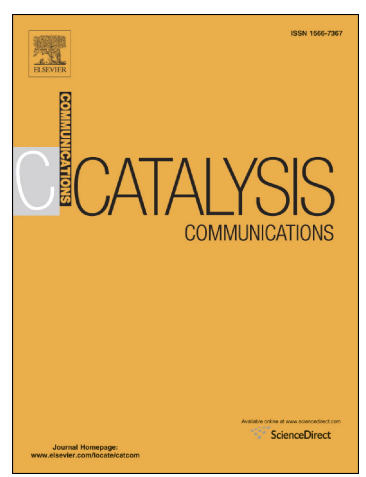

PII:

S1566-7367(18)30239-5

DOI: doi:10.1016/j.catcom.2018.07.001

Reference: CATCOM 5441

To appear in:

\section{Catalysis Communications}

Received date:

10 March 2018

Revised date:

23 June 2018

Accepted date:

1 July 2018

Please cite this article as: Hamidreza Arandiyan, Ghasem Kasaeian, Behzad Nematollahi, Yuan Wang, Hongyu Sun, Stuart Bartlett, Hongxing Dai, Mehran Rezaei, Self-assembly of flower-like LaNiAlO3-supported nickel catalysts for CO methanation. Catcom (2018), doi:10.1016/j.catcom.2018.07.001

This is a PDF file of an unedited manuscript that has been accepted for publication. As a service to our customers we are providing this early version of the manuscript. The manuscript will undergo copyediting, typesetting, and review of the resulting proof before it is published in its final form. Please note that during the production process errors may be discovered which could affect the content, and all legal disclaimers that apply to the journal pertain. 


\title{
Self-assembly of flower-like $\mathrm{LaNiAlO}_{3}$-supported nickel catalysts for CO methanation
}

\author{
Hamidreza Arandiyan ${ }^{\mathrm{a}, *}$, Ghasem Kasaeian ${ }^{\mathrm{b}}$, Behzad Nematollahi ${ }^{\mathrm{c}}$, Yuan Wang ${ }^{\mathrm{d}}$, \\ Hongyu Sun ${ }^{\mathrm{e}}$, Stuart Bartlett ${ }^{\mathrm{a}}$, Hongxing Dai ${ }^{\mathrm{f}, *}$, Mehran Rezaei ${ }^{\mathrm{c}, *}$
}

${ }^{a}$ Laboratory of Advanced Catalysis for Sustainability, School of Chemistry, The University of Sydney, Sydney 2006, Australia

${ }^{\mathrm{b}}$ Department of Chemical Engineering, Amirkabir University of Technology, Tehran, Iran

${ }^{\mathrm{c}}$ Catalyst and Advanced Materials Research Laboratory, Chemical Engineering Department, University of Kashan, Kashan, Iran

${ }^{\mathrm{d}}$ Particles and Catalysis Research Group, School of Chemical Engineering, The University of New South Wales, Sydney 2052, Australia

${ }^{\mathrm{e}}$ Department of Micro- and Nanotechnology, Technical University of Denmark, Kongens Lyngby 2800, Denmark

${ }^{\mathrm{f}}$ Beijing Key Laboratory for Green Catalysis and Separation, Department of Chemistry and Chemical Engineering, College of Environmental and Energy Engineering, Beijing University of Technology, Beijing 100124, China

*Corresponding Authors. E-mail addresses hamid.arandiyan@sydney.edu.au (H. Arandiyan), hxdai@bjut.edu.cn (H. Dai), and rezaei@kashanu.ac.ir (M. Rezaei). 


\begin{abstract}
A series of supported $\mathrm{Ni}$ nanoparticles on a flower-like porous $\mathrm{LaNi}_{0.6} \mathrm{Al}_{0.4} \mathrm{O}_{3}$ (LNAO) perovskite carrier $(z \mathrm{Ni} / \mathrm{LNAO} ; z=5,10$ and $15 \mathrm{wt} \%)$ were successfully synthesized using a controlled self-assembly sol-gel method. The experimental results showed that the presence of Ni nanoparticles markedly enhanced the reaction rate of $\mathrm{CO}$ conversion, namely from 12.4 $\mathrm{mmol} /\left(\mathrm{g}_{\text {cat }} \mathrm{h}\right)$ over LNAO to $244 \mathrm{mmol} /\left(\mathrm{g}_{\text {cat }} \mathrm{h}\right)$ over $10 \mathrm{wt} \% \mathrm{Ni} / \mathrm{LNAO}$. The porous LNAO perovskite support provides both a large surface area to well disperse Ni nanoparticles and active sites for the methanation reaction, thus resulting in a catalyst with activity (per gram of catalyst basis) at least comparable to other nickel metal-based supported catalysts reported so far and with very good stability. Reaction rates calculated based on Ni exposed surface and total $\mathrm{Ni}$ amount revealed that $\mathrm{Ni}$ active sites in the $\mathrm{Ni}$ nanoparticles and bulk perovskite were distinct.
\end{abstract}

Keywords: Self-assembly; Flower-like porous material; Al-substituted lanthanum nickelate; Perovskite-supported Ni catalyst; CO methanation. 


\section{Introduction}

Conversion of carbon monoxide to methane through hydrogenation, which is named CO methanation, is an effective technology for energy applications. Recently, attention has been paid on CO methanation as a practical technology and an operative methodology for fuel gas clean up [1, 2]. Synthetic natural gas $(\mathrm{SNG})$ is produced via gasification of coal [3] and biomass $[4,5]$, which then can generate synthetic gas (syngas, a mixture of $\mathrm{CO} / \mathrm{H}_{2}$ ) via steam reforming (SMR) and WGS reaction processes [6-8]. The product gas stream from the latter processes contains $1-20 \% \mathrm{CO}$ and the rest is $\mathrm{H}_{2}$. One of the common methods for removing $\mathrm{CO}$ from the reformate gas (pure hydrogen production) is preferential oxidation of $\mathrm{CO}$ (PROX) [9]. Methanation of $\mathrm{CO}\left(\mathrm{CO}+3 \mathrm{H}_{2} \leftrightarrow \mathrm{CH}_{4}+\mathrm{H}_{2} \mathrm{O}, \Delta \mathrm{H}^{\circ}=-206 \mathrm{~kJ} / \mathrm{mol}\right)$ is another pathway to reduce the $\mathrm{CO}$ content in reformate gas [1]. Compared with the PROX process, methanation of $\mathrm{CO}$ has the advantage of no air $\left(\right.$ or $\left.\mathrm{O}_{2}\right)$ addition to the reformate gas stream, which prevents from safety issues [10]. $\mathrm{Fe}, \mathrm{Co}, \mathrm{Ni}$, and $\mathrm{Ru}$ show sufficiently high activities for the hydrogenation of carbon monoxide [11-13].

Although noble metal-based catalysts have been widely investigated to inhibit coking as compared to Ni-based catalysts, some disadvantages (e.g. easy agglomeration and high cost) limit their wide application [14]. For this reason, research on developing highly active and selective Ni-based catalysts with less coke deposition is of great importance $[15,16]$. Several studies have categorized the type of carbon deposited on Ni-based catalysts [17-19]. Recently, Vasiliades et al. $[18,19]$ extended the knowledge in this field (carbon deposition via $\mathrm{CH}_{4}$ and $\mathrm{CO}$ dissociation) and enabled understanding of the actual redox-promotional role of reducible metal oxide supports through a series of steady-state isotopic transient kinetic analysis (SSITKA) experiments.

An attractive alternative is to use $\mathrm{Ni}$ as active phase together with other transition metals to form perovskite-type oxides $\left(\mathrm{ABO}_{3}\right)$. Replacement of part of $\mathrm{A}$ or $\mathrm{B}$ ions with other cations brings about modifications on catalytic activity, selectivity and stability of an $\mathrm{ABO}_{3}$ at comparatively high temperatures $\left(700-900{ }^{\circ} \mathrm{C}\right)$ with relatively less deactivation (i.e. sintering 
and chemical degradation) [20] by adjusting the metal oxidation states, structural defects and oxygen lattice mobility [21]. Additionally, $\mathrm{ABO}_{3}$ after hydrogen reduction treatment allows to obtain small particles, in which high metal dispersion can reduce coke deposition on the surface of the catalyst. Such a high metal dispersion could also lead to suppression of coke formation and good resistance to environmental pollution [22]. In the past years, several researchers have investigated preparation and physicochemical properties of $\mathrm{ABO}_{3}$. For instance, Khalesi et al. [23] reported that the catalytic activity of $\mathrm{M}_{\mathrm{x}} \mathrm{La}_{1-\mathrm{x}} \mathrm{Ni}_{0.3} \mathrm{Al}_{0.7} \mathrm{O}_{3}(\mathrm{M}=\mathrm{K}$, $\mathrm{Na}$, and $\mathrm{Li}$ ) for carbon dioxide reforming markedly increased by the tuning of highly basic Li, $\mathrm{Na}$, and $\mathrm{K}$, and coke formation was greatly suppressed over $\mathrm{Li}_{0.2} \mathrm{La}_{0.8} \mathrm{Ni}_{0.3} \mathrm{Al}_{0.7} \mathrm{O}_{2.8}$ and $\mathrm{Na}_{0.5} \mathrm{La}_{0.5} \mathrm{Ni}_{0.3} \mathrm{Al}_{0.7} \mathrm{O}_{2.5}$ displayed high yield of the desired product, and $\mathrm{K}_{0.5} \mathrm{La}_{0.5} \mathrm{Ni}_{0.3} \mathrm{Al}_{0.7} \mathrm{O}_{2.5}$ showed an $\mathrm{H}_{2} / \mathrm{CO}$ ratio close to one in a broad temperature range.

Working on the characterization of $\mathrm{LaNi}_{\mathrm{x}} \mathrm{Al}_{1-\mathrm{x}} \mathrm{O}_{3}(0.1 \leq \mathrm{x} \leq 0.9)$, Parvary et al. [24] found that the gradual substitution of $\mathrm{Ni}$ by $\mathrm{Al}$ could induce the reduction of $\mathrm{LaNiO}_{3}$ to $\mathrm{La}_{2} \mathrm{NiO}_{5}$ and $\mathrm{Ni} / \mathrm{La}_{2} \mathrm{O}_{3}$. Furthermore, addition of $\mathrm{Al}$ to the $\mathrm{LaNiO}_{3}$ perovskite structure changed the $\mathrm{Ni}$ reduction temperature and the stability of the catalyst under reduction conditions that could limit the migration of the active $\mathrm{Ni}$ [23]. Over the past several years, our group has investigated several physicochemical and catalytic properties of the porous or micro/nanostructured materials with well-defined morphologies (e.g., $\mathrm{La}_{0.6} \mathrm{Sr}_{0.4} \mathrm{MnO}_{3}$ [25-27], $\mathrm{La}_{0.5} \mathrm{Sr}_{0.5} \mathrm{CoO}_{3}$ [28], $\mathrm{LaNi}_{\mathrm{x}} \mathrm{Fe}_{1-\mathrm{x}} \mathrm{O}_{3}$ [29], $\mathrm{La}_{0.4} \mathrm{M}_{0.6} \mathrm{Al}_{0.2} \mathrm{Ni}_{0.8} \mathrm{O}_{3}(\mathrm{M}=\mathrm{Pt}, \mathrm{Pd}, \mathrm{Ir}, \mathrm{Rh}, \mathrm{Ru})$ [30], and $\left.\mathrm{NiCo}_{2} \mathrm{O}_{4}[31,32]\right)$. It was found that most of the porous materials performed well for the catalytic oxidation of hydrocarbons and/or methanation reactions. Nevertheless, no detailed works on the synthesis and catalytic applications for the $\mathrm{CO}$ methanation over $\mathrm{LaNi}_{\mathrm{x}} \mathrm{Al}_{1-\mathrm{x}} \mathrm{O}_{3}$ $(\mathrm{x}=0.1,0.4,0.6$, and 0.9$)$ appeared so far. It might be expected that the strong interaction between $\mathrm{Ni}$ and $\mathrm{LaNi}_{\mathrm{x}} \mathrm{Al}_{1-\mathrm{x}} \mathrm{O}_{3}$ could enhance catalytic activity.

Herein, we report the synthesis, physicochemical characterization and catalytic activities of flower-like porous $\mathrm{Ni}$ substituted $\mathrm{LaAlO}_{3}$ perovskite-supported $\mathrm{Ni}$ using a 
controlled self-assembly sol-gel method for the $\mathrm{CO}$ methanation reaction. After primary investigation, the $\mathrm{Ni} / \mathrm{Al}$ molar ratio was fixed to the value $6 / 4\left(\mathrm{LaNi}_{0.6} \mathrm{Al}_{0.4} \mathrm{O}_{3}\right)$ due to the optimal catalytic performance for $\mathrm{CO}$ methanation as depicted in Fig. S1 (ESI). Ni nanoparticles (NPs) loading on the porous $\mathrm{LaNi}_{0.6} \mathrm{Al}_{0.4} \mathrm{O}_{3}$ (LNAO) support significantly improved the $\mathrm{CO}$ methanation activity. Important physicochemical properties of the $z \mathrm{Ni} / \mathrm{LNAO}(z=5,10$, and $15 \mathrm{wt} \%)$ catalysts were characterized and attempts were made to correlate these properties with their catalytic behaviour. The active sites of Ni present on the surface of Ni NPs and LNAO perovskite support have also been investigated.

\section{Experimental}

Details of catalysts synthesis (Scheme S1 and Fig. S2) are described in the Electronic Supplementary Information (ESI). The CO methanation activity evaluation over the various catalysts investigated was conducted according to the procedures described in ESI (Section 2.7, Fig. S3). All of the catalysts were characterized by $\mathrm{N}_{2}$ adsorption-desorption (BrunauerEmmett-Teller, BET), transmission electron microscopy (TEM), scanning electron microscopy (SEM), energy-dispersive spectroscopy (EDS), powder X-ray diffraction (XRD), temperature-programmed desorption of carbon monoxide (CO-TPD), and $\mathrm{H}_{2}$ temperatureprogrammed reduction $\left(\mathrm{H}_{2}-\mathrm{TPR}\right)$, and these characterization procedures are described in the ESI (see Sections 2.1-2.6).

\section{Results and discussion}

The LNAO and Ni/LNAO samples were successfully synthesized by a controlled solgel strategy, which provided small-sized Ni NPs and uniformly dispersed on the surface of the flower-like porous LNAO (Scheme S1, ESI). Structures and morphologies of the catalytic samples were observed by the SEM and TEM techniques (Fig. 1a-c, Fig. S4-8). As shown in Fig. 1a and Fig. S4a, the LNAO contains a number of sheets forming a flower-like porous 
morphology. The irregular sheets of $300-800 \mathrm{~nm}$ in length and $30-50 \mathrm{~nm}$ in thickness were densely packed. Having a closer observation of Fig. S4b, one can see that the flower-structure in the hole depicted exhibits more loose-packed morphology than the structure on the surface. The SEM images (Fig. S4b-d) imply that different Ni loadings (5, 10 and $15 \mathrm{wt} \%$ ) on the LNAO support did not change the overall flower-like porous morphology. The EDS elemental mapping profiles visualized the elemental composition and dispersion of the $10 \mathrm{wt} \%$ $\mathrm{Ni} / \mathrm{LANO}$ sample (Fig. S4e-j). It can be observed that $\mathrm{La}, \mathrm{Ni}, \mathrm{Al}$ and $\mathrm{O}$ elements were evenly distributed within the nanostructures, confirming the formation of a uniform LNAO perovskite material and a good dispersion of Ni NPs on the support (ca. $10 \mathrm{wt} \% \mathrm{Ni} / \mathrm{LNAO}$ (Fig. 1a)).

To identify the structural morphology of Ni NPs, TEM characterization was also conducted. Fig. 1b-c and Fig. S5 show TEM images obtained for the LNAO and $z$ Ni/LNAO samples. It should be noted that after the fragmentation of the flower-like porous LNAO by the power density of ultrasound in ethanol solution (sample pre-treatment before TEM observation), pieces of nanosheets were detected in the TEM images. A number of macrostructures with mesopores were recorded in the LNAO nanosheets with average pore sizes in the range of 20-50 nm (Fig. S5). Highly dispersed and uniformly sized Ni NPs were observed on the surface of LNAO, as indicated in the 5 and $10 \mathrm{wt} \% \mathrm{Ni} / \mathrm{LNAO}$ samples, where the average particle size is estimated to be $\sim 10 \mathrm{~nm}$ (Figs. S6-S8). When Ni loading increased to $15 \mathrm{wt} \%$, agglomeration of Ni NPs appeared, and the average particle size increased to $\sim 12$ nm. From HR-TEM images obtained for the $15 \mathrm{wt} \% \mathrm{Ni} / \mathrm{LNAO}$, an inter-planar spacing $(d$ value) of $0.26 \mathrm{~nm}$ corresponding to the (110) plane of the standard $\mathrm{LaNiO}_{3}$ sample (JCPDS PDF\# 50-0308) was estimated. The nanosheets forming the flower-like morphology might be derived from the cetytrimethylammonium bromide (CTAB) added during the preparation process of LNAO. The CTAB-mediated route resulted in a high-quality mesoporous structure 
(as illustrated by the arrows of Fig. 1b) and prevented the morphological structure against conglomeration.

Further evidence of the porous structure of prepared supports arises from the $\mathrm{N}_{2}$ adsorption-desorption isotherms, in which all of the samples exhibited a similar type-II isotherm and type $\mathrm{H} 2\left(\mathrm{p} / \mathrm{p}_{0}=0.3-0.7\right)$ and $\mathrm{H} 3\left(p / p_{0}=0.7-1.0\right)$ hysteresis loops, indicating the presence of macropores and mesopores in the LNAO samples. The LNAO-supported Ni samples showed larger hysteresis loops than that of the LNAO support, demonstrating that introduction of Ni NPs consequently modifies the porous structure (pore size and distribution) of LNAO (Fig. S9a). The BET surface areas of the LNAO and $z \mathrm{Ni} / \mathrm{LNAO}$ samples are provided in Table 1. The BET surface area $\left(21.1-25.4 \mathrm{~m}^{2} / \mathrm{g}\right)$ of the $z$ Ni/LNAO samples is found to be larger than that of the LNAO support alone $\left(9.1 \mathrm{~m}^{2} / \mathrm{g}\right)$, which might be caused by surface modifications from the impregnation process using nickel nitrate, thus leading to the variation of surface roughness.

The powder XRD patterns of the LNAO and $z$ Ni/LNAO samples are shown in Fig. S9b. All of the samples were highly crystalline. The characteristic diffraction peaks at $2 \theta=$ $22.3^{\circ}, 32.8^{\circ}, 40.6^{\circ}, 47.3^{\circ}, 53.5^{\circ}, 59.1^{\circ}, 69.6^{\circ}, 79.4^{\circ}, 84.1^{\circ}$, and $89.1^{\circ}$ correspond to the $(012)$, (110), (202), (024), (116), (300), (220), (306), (134), and (226) lattice crystal planes of the rhombohedral $\mathrm{LaAlO}_{3}$ perovskite phase (JCPDS PDF\# 50-0308), respectively. The characteristic powder XRD peaks of $\mathrm{Ni}$ phases $\left(\mathrm{Ni}^{0}\right.$ and/or $\left.\mathrm{NiO}\right)$ were very weak to be identified by XRD. 

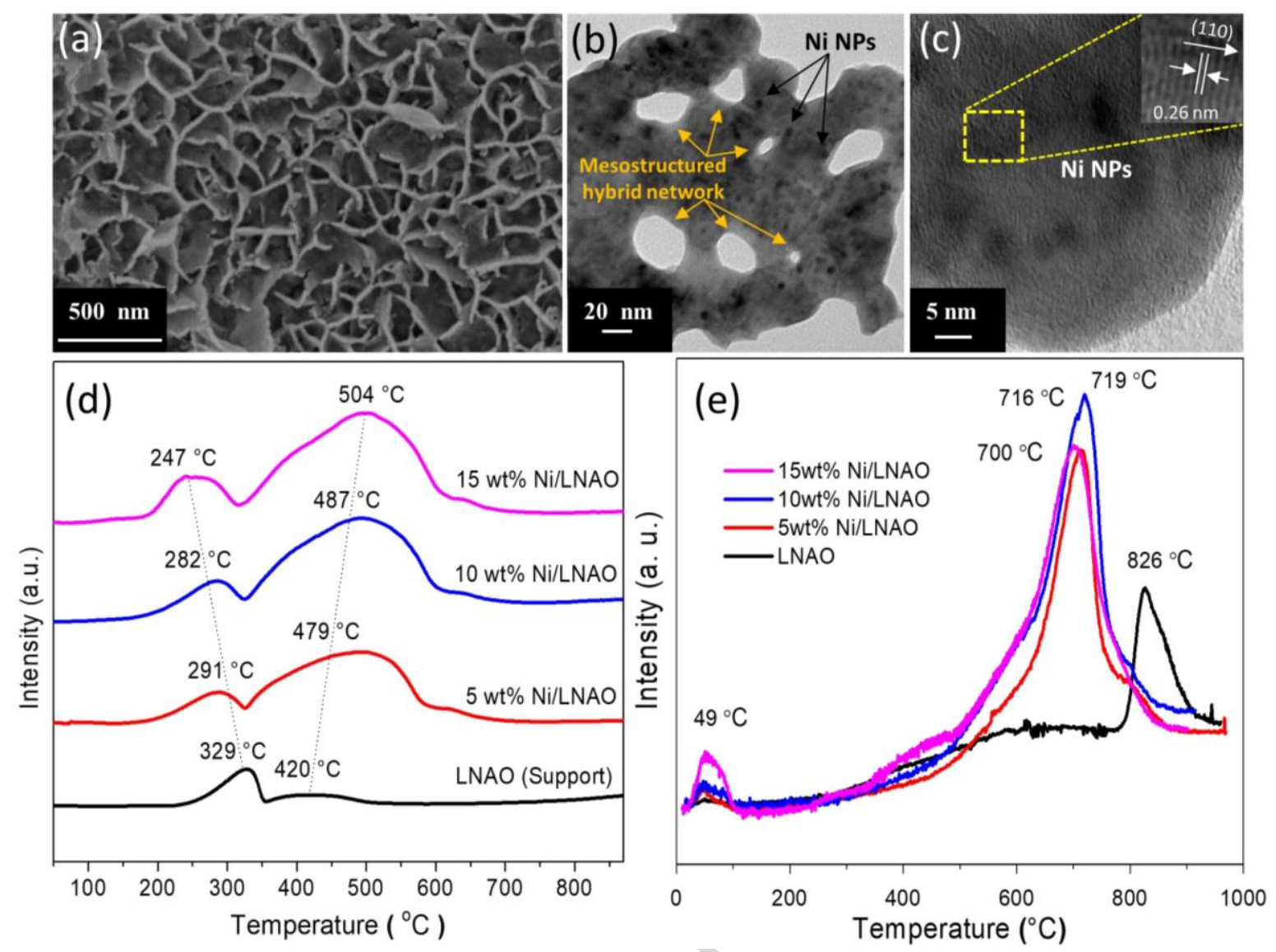

Fig. 1. (a) SEM image of $10 \mathrm{wt} \% \mathrm{Ni} / \mathrm{LNAO}$, (b) TEM image of $5 \mathrm{wt} \% \mathrm{Ni} / \mathrm{LNAO}$, (c) TEM image of $15 \mathrm{wt} \% \mathrm{Ni} / \mathrm{LNAO}$, (d) $\mathrm{H}_{2}$-TPR profiles and (e) CO-TPD profiles of samples.

The reducibility of the as-prepared samples was studied using the $\mathrm{H}_{2}$-TPR technique, and the obtained results are presented in Fig. 1d. It should be noted that La and Al had no reduction responses under the applied $\mathrm{H}_{2}$-TPR conditions, since $\mathrm{La}$ and $\mathrm{Al}$ oxides were irreducible below $1000{ }^{\circ} \mathrm{C}$. Thus, the TPR peaks were due to the several reduction steps of $\mathrm{Ni}$ with different oxidation states. The reduction of $\mathrm{Ni}$ ions in $\mathrm{LNAO}$ and $z \mathrm{Ni} / \mathrm{LNAO}$ takes place according to a two-step process: (i) the reduction peak in the temperature range $250-300{ }^{\circ} \mathrm{C}$ is related to the reduction of $\mathrm{Ni}^{3+}$ to $\mathrm{Ni}^{2+}$, and (ii) the reduction peak in the higher temperature range of $430-500{ }^{\circ} \mathrm{C}$ is associated with the reduction of $\mathrm{Ni}^{2+}$ to metallic nickel $\left(\mathrm{Ni}^{0}\right)$ [33]. As the Ni loading increases the relative intensity of the high-temperature peak in $\mathrm{H}_{2}$-TPR profiles increases. It can be suggested that the increase in $\mathrm{Ni}$ content gradually increases the amount (per gram) of nickel species in the catalyst support. The estimated $\mathrm{H}_{2}$ consumption in the 250$300{ }^{\circ} \mathrm{C}$ range is nearly the same as the $\mathrm{H}_{2}$ amount needed for the reduction of $\mathrm{Ni}^{3+}$ to $\mathrm{Ni}^{2+}$ [23]. 
The $\mathrm{H}_{2}$ consumption in the $430-500{ }^{\circ} \mathrm{C}$ range also supports the view that the peak in this higher temperature range is due to the reduction of $\mathrm{Ni}^{2+}$ to $\mathrm{Ni}^{0}$. It can be observed that the reduction peak associated with the first reduction step of $\mathrm{Ni}$ ions in the $z \mathrm{Ni} / \mathrm{LNAO}$ samples slightly shifted towards lower temperatures (from 391 to $247^{\circ} \mathrm{C}$ ), and reduction peaks associated with the second reduction step shifted towards higher temperatures (from 420 to $504{ }^{\circ} \mathrm{C}$ ) with the increase of $\mathrm{Ni}$ loading. This result indicates that oxidized $\mathrm{Ni}$ in the presence of nanoparticles on the support is more likely to be reduced than oxidized $\mathrm{Ni}$ in the crystal lattice of the perovskite structure $\left(\mathrm{LaNi}_{0.6} \mathrm{Al}_{0.4} \mathrm{O}_{3}\right)$. The large peak area of the peaks at higher temperatures (from 420 to $504{ }^{\circ} \mathrm{C}$ ) for $\mathrm{Ni}$ loading samples also suggests a large amount of $\mathrm{Ni}$ ${ }^{2+}$ species present in the nickel nanoparticles.

The CO-TPD experiment was performed in order to investigate the adsorption types of $\mathrm{CO}$ species on the surface of LNAO and $z \mathrm{Ni} / \mathrm{LNAO}$ catalysts. Two peaks were observed for each catalyst composition (Fig. 1e). The low-temperature desorption peak recorded at $40-50{ }^{\circ} \mathrm{C}$ is ascribed to $\mathrm{CO}$ molecules weakly bonded to the catalyst surface, whereas the high-temperature desorption peak recorded at $700-826{ }^{\circ} \mathrm{C}$ is assigned to a very strongly chemisorbed $\mathrm{CO}$ species. However, the possibility that part of this high-T desorbed CO might be the result of recombination of C-s and O-s after $\mathrm{CO}$ dissociation at lower T's during the experiment cannot be excluded. The characteristic profiles were practically very similar to those previously reported [2]. Upon the loading of Ni NPs, the intensity of the lowtemperature desorption peak increased significantly, while the high-temperature peak gradually shifted to lower temperatures and its intensity is obviously enhanced. This result indicates that the loading of Ni NPs has modified the CO chemisorptive and dissociation abilities of the LNAO catalyst surface. Among the catalysts investigated $10 \mathrm{wt} \% \mathrm{Ni} / \mathrm{LNAO}$ showed the largest amount of high-T desorbed $\mathrm{CO}\left(\mathrm{ca} .720{ }^{\circ} \mathrm{C}\right.$ ) and a small peak at ca. $50{ }^{\circ} \mathrm{C}$, suggesting an improved CO adsorption ability in terms of concentration (mols $/ \mathrm{g}_{\mathrm{cat}}$ ). 
The methanation of $\mathrm{CO}$ was carried out in a fixed-bed microreactor in the range of 200-300 ${ }^{\circ} \mathrm{C}$. Fig. S10 illustrates that the $\mathrm{CO}$ methanation activity is largely improved by introducing Ni NPs when compared to the pure LNAO support. More precisely, a $30-50{ }^{\circ} \mathrm{C}$ lower temperature is obtained for $50 \% \mathrm{CO}$ conversion compared to the pure LNAO support $\left(268{ }^{\circ} \mathrm{C}\right)$. Reaction $\mathrm{CH}_{4}$-selectivity results are shown in Fig. S11. These results demonstrate the significant promotional effect of Ni NPs towards $\mathrm{CH}_{4}$ selectivity. In particular, $\mathrm{CH}_{4}$ selectivity nearly $100 \%$ is observed over the $10 \mathrm{wt} \% \mathrm{Ni} / \mathrm{LNAO}$, while that of LNAO is only $60 \%$ at $220{ }^{\circ} \mathrm{C}$. During $\mathrm{CO}$ methanation reaction at $220{ }^{\circ} \mathrm{C}$, a small concentration of $\mathrm{CO}_{2}$ was detected as a by-product over the $5 \mathrm{wt} \% \mathrm{Ni} / \mathrm{LNAO}$ and $10 \mathrm{wt} \% \mathrm{Ni} / \mathrm{LNAO}$ catalysts. Based on some proposed mechanisms [34, 35] for the $\mathrm{CO}$ methanation reaction, the step of $\mathrm{CO}$ dissociation is a slower step than others. At low reaction temperatures, where the rate of methanation reaction is small (there is not enough energy to effectively dissociate adsorbed $\mathrm{CO}$ followed by hydrogenation of derived $\mathrm{C}-\mathrm{s}$ species), the probability for $\mathrm{CO}$ disproportionation reaction only $\left(2 \mathrm{CO} \rightarrow \mathrm{CO}_{2}+\mathrm{C}\right.$ ) increases (ca. $100 \square \mathrm{C}$, [36]).

The activity results (Fig. 2) suggest that $\mathrm{Ni}$ on the surface of LNAO perovskite and nickel NPs serve as active sites for CO methanation. To distinguish their activation ability, the reaction rate of $\mathrm{CO}$ conversion, normalized by the catalyst mass $\left(\mathrm{mmol} / \mathrm{g}_{\mathrm{cat}} / \mathrm{h}\right)$, the surface $\mathrm{Ni}$ $(\mathrm{Ni}, \mathrm{s})$ in NPs $\left(\mathrm{mol} / \mathrm{mol}_{\mathrm{Ni}, \mathrm{s}} / \mathrm{h}\right)$ and the $\mathrm{Ni}$ total molar amount $\left(\mathrm{mol} / \mathrm{mol}_{\mathrm{Ni}}\right.$ total $\left./ \mathrm{h}\right)$, was calculated for comparison. As shown in Fig. 2 and Table 1, the reaction rate per gram of catalyst follows the same trend as the CO conversion vs temperature profile, decreasing in the order: $10 \mathrm{wt} \%$ $\mathrm{Ni} / \mathrm{LNAO}\left(244 \mathrm{mmol} / \mathrm{g}_{\text {cat }} / \mathrm{h}\right)>5 \mathrm{wt} \% \mathrm{Ni} / \mathrm{LNAO}\left(238 \mathrm{mmol} / \mathrm{g}_{\text {cat }} / \mathrm{h}\right)>15 \mathrm{wt} \% \mathrm{Ni} / \mathrm{LNAO}$ $\left(4.81 \mathrm{mmol} / \mathrm{g}_{\text {cat }} / \mathrm{h}\right)>\operatorname{LNAO}\left(12.4 \mathrm{mmol} / \mathrm{g}_{\text {cat }} / \mathrm{h}\right)$. The reaction rate of $10 \mathrm{wt} \% \mathrm{Ni} / \mathrm{LNAO}$ is about 20 times higher than that obtained over pure LNAO, demonstrating the outstanding activity of Ni active sites in NPs.

The raction rate calculated on the basis of surface Ni in the NPs $\left(279 \mathrm{~mol} / \mathrm{mol}_{\mathrm{Nis}} / \mathrm{h}\right)$ and of the total $\mathrm{Ni}$ in the sample $\left(72.1 \mathrm{~mol} / \mathrm{mol}_{\mathrm{Ni} \text { total }} / \mathrm{h}\right)$ is the highest for the $5 \mathrm{wt} \% \mathrm{Ni} / \mathrm{LNAO}$ 
among the other samples. These results suggest an optimal Ni loading of $5 \mathrm{wt} \% \mathrm{Ni}$ that exhibits practically the best reaction rate of $\mathrm{CO}$ conversion at $220{ }^{\circ} \mathrm{C}$ when the latter is expressed per unit mass of catalyst or per surface Ni sites (TOF, $\left.\mathrm{h}^{-1}\right)$.

The factors which influence the activity of supported catalysts mainly include: the nature of support and loaded active metal, the particle size and dispersion of metal and the metal-support interactions [11]. Comparing the reaction rate based on the surface Ni sites (TOF, $\mathrm{h}^{-1}$, Table 1), it can be concluded that the homogeneous dispersion and moderate metalsupport interactions developed between the $5 \mathrm{wt} \% \mathrm{Ni}$ and the LNAO support result in the best activity for $\mathrm{CO}$ methanation. A comparison of $\mathrm{CO}$ methanation rate (mols $\mathrm{CO} / \mathrm{g}_{\text {cat }} / \mathrm{h}$ ) over several heterogeneous very active catalysts is summarized in Table S1. Obviously, the catalytic activity over $z \mathrm{Ni} / \mathrm{LNAO}$ (Table 1) is at least comparable to that exhibited by alumina-supported and other nickel metal catalysts, where the former showed the highest catalytic performance.

To evaluate the stability of the best-performing catalyst, a long-term $\mathrm{CO}$ methanation reaction at $225{ }^{\circ} \mathrm{C}(\mathrm{CO}$ conversion $<100 \%)$ was conducted over the $10 \mathrm{wt} \% \mathrm{Ni} / \mathrm{LNAO}$ catalyst. As shown in Fig. S12, the $10 \mathrm{wt} \% \mathrm{Ni} / \mathrm{LNAO}$ sample exhibits a very good catalytic stability, with a slight only activity drop $(<10 \%)$ after $60 \mathrm{~h}$ on time-of-stream. The possibility for coke formation was also investigated by TPO analysis on the aged $10 \mathrm{wt} \% \mathrm{Ni} / \mathrm{LNAO}$ sample after the 60-h stability test. The result obtained is presented in Fig. S13. No obvious coke formation can be seen.

Table 1. BET surface areas, catalytic activities (CO conversion rate at $220{ }^{\circ} \mathrm{C}$ per $\mathrm{g}_{\text {cat }}$, per $\mathrm{mol}_{\mathrm{Ni}, \mathrm{s}}$ and per $\mathrm{mol}_{\mathrm{Ni} \text { total }}$ of the $5 \mathrm{wt} \% \mathrm{Ni} / \mathrm{LNAO}, 10 \mathrm{wt} \% \mathrm{Ni} / \mathrm{LNAO}, 15 \mathrm{wt} \% \mathrm{Ni} / \mathrm{LNAO}$ and LNAO samples.

\begin{tabular}{|c|c|c|c|c|}
\hline \multirow{2}{*}{ Sample } & \multirow{2}{*}{$\begin{array}{c}\text { BET } \\
\text { surface area } \\
\left(\mathrm{m}^{2} / \mathrm{g}\right)\end{array}$} & \multicolumn{3}{|c|}{$\mathrm{CO}$ conversion rate at $220^{\circ} \mathrm{C}$} \\
\hline & & $\mathrm{mmol} / \mathrm{g}_{\text {cat }} / \mathrm{h}$ & $\mathrm{mol} / \mathrm{mol}_{\mathrm{Ni}, \mathrm{S}} / \mathrm{h}$ & $\mathrm{mol} / \mathrm{mol}_{\mathrm{Ni} \text { total }} / \mathrm{h}$ \\
\hline LNAO & 9.1 & 4.81 & & 1.86 \\
\hline $5 \mathrm{wt} \% \mathrm{Ni} / \mathrm{LNAO}$ & 21.1 & 238 & 279 & 72.1 \\
\hline $10 \mathrm{wt} \% \mathrm{Ni} / \mathrm{LNAO}$ & 21.5 & 244 & 143 & 60.6 \\
\hline $15 \mathrm{wt} \% \mathrm{Ni} / \mathrm{LNAO}$ & 25.4 & 12.4 & 4.83 & 2.61 \\
\hline
\end{tabular}




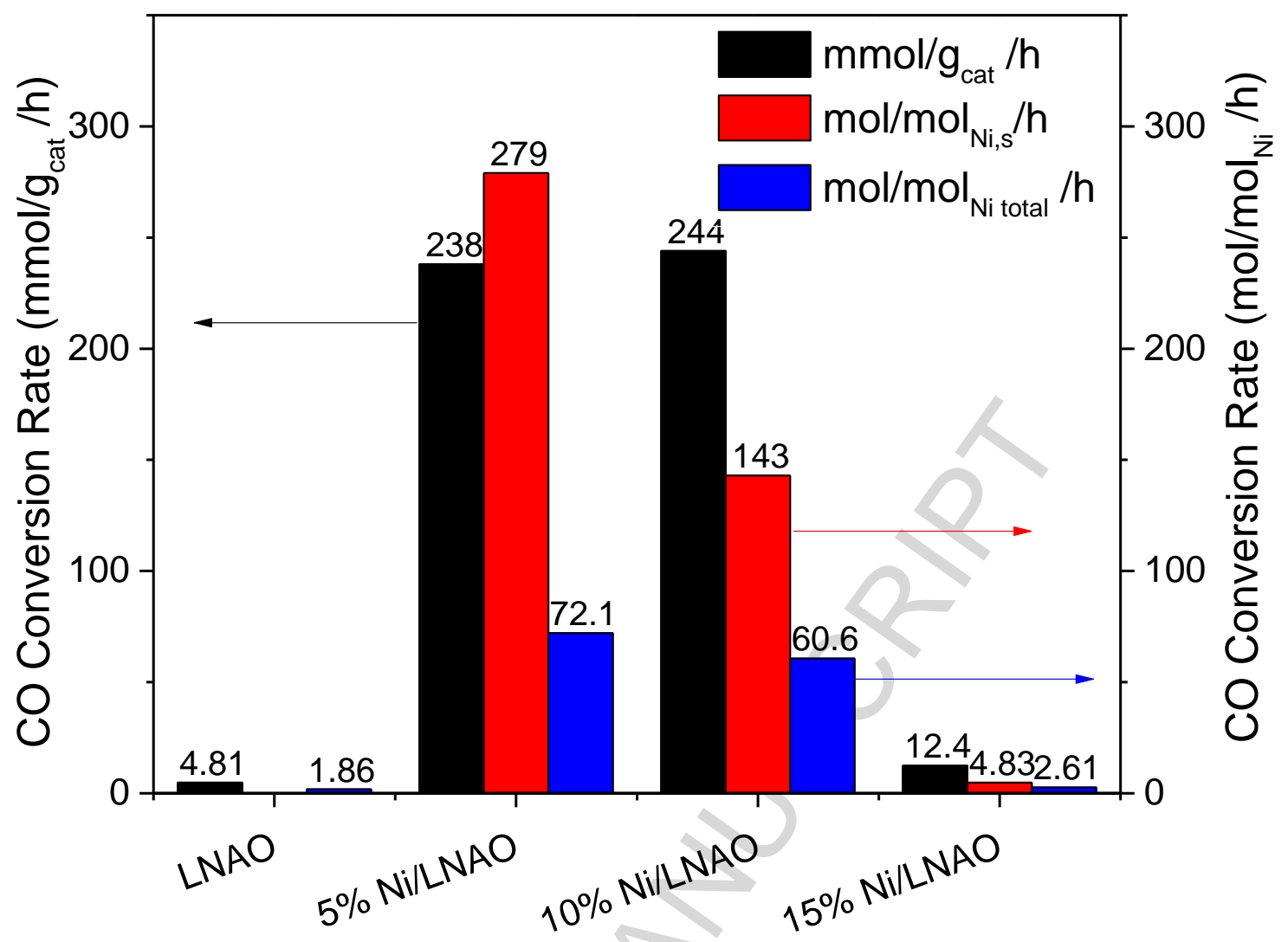

Fig. $2 \mathrm{CO}$ conversion rate normalized by catalyst mass (black bar, $\mathrm{mmol} / \mathrm{g}_{\mathrm{cat}} / \mathrm{h}$ ), Ni surface sites in NPs (red bar, $\mathrm{mol} / \mathrm{mol}_{\mathrm{Ni}, \mathrm{s}} / \mathrm{h}$ ) and Ni total molar weight (blue bar, $\mathrm{mol} / \mathrm{mol}_{\mathrm{Ni}}$ total $/ \mathrm{h}$ ) of LNAO, $5 \mathrm{wt} \%$ $\mathrm{Ni} / \mathrm{LNAO}, 10 \mathrm{wt} \% \mathrm{Ni} / \mathrm{LNAO}$ and $15 \mathrm{wt} \% \mathrm{Ni} / \mathrm{LNAO}$.

\section{Conclusions}

In summary, Ni/LNAO samples (Ni loading 5-15 wt\%) with a flower-like porous morphology was synthesized using a simple sol-gel method. It was found that the loading of $\mathrm{Ni}$ NPs on the surface of LNAO support modified the catalytic activity towards CO methanation of the catalysts. The outstanding reaction rate over the Ni-loaded LNAO catalysts was found to be largely due to $\mathrm{Ni}$ active sites on the surface of Ni NPs which possessed higher intrinsic activity than the $\mathrm{Ni}$ sites on the surface of LNAO for the $\mathrm{CO}$ methanation. The appropriate Ni dispersion and metal-support interactions developed in the 5 wt $\% \mathrm{Ni} / \mathrm{LNAO}$ catalyst resulted in the excellent catalytic performance when compared to other active Ni-based supported metal catalysts reported in the open literature. 


\section{Acknowledgements}

H.A. acknowledges financial support through the Research Fellowship (L0915/U2403) from

The University of Sydney and Australian Research Council under Discovery Project Scheme - DP170104853.

\section{Appendix A. Supplementary material}

Supplementary data associated with this article can be found, in the online version, at http://dx.doi.org/10.1016/j.cej.2018.XX.XXX.

\section{References}

[1] B. Nematollahi, M. Rezaei, E.N. Lay, Preparation of highly active and stable $\mathrm{NiO}-\mathrm{CeO}_{2}$ nanocatalysts for $\mathrm{CO}$ selective methanation, International Journal of Hydrogen Energy, 40 (2015) 8539-8547.

[2] B. Nematollahi, M. Rezaei, E. Amini, E. Nemati Lay, Preparation of high surface area $\mathrm{Ni} / \mathrm{MgAl}_{2} \mathrm{O}_{4}$ nanocatalysts for $\mathrm{CO}$ selective methanation, International Journal of Hydrogen Energy, 43 (2018) 772-780.

[3] M. Minutillo, A. Perna, Renewable energy storage system via coal hydrogasification with co-production of electricity and synthetic natural gas, International Journal of Hydrogen Energy, 39 (2014) 5793-5803.

[4] H. Jahangiri, J. Bennett, P. Mahjoubi, K. Wilson, S. Gu, A review of advanced catalyst development for Fischer-Tropsch synthesis of hydrocarbons from biomass derived syn-gas, Catalysis Science \& Technology, 4 (2014) 2210-2229.

[5] Y. Wang, S. De, N. Yan, Rational control of nano-scale metal-catalysts for biomass conversion, Chemical Communications, 52 (2016) 6210-6224.

[6] C.M. Kalamaras, D.D. Dionysiou, A.M. Efstathiou, Mechanistic Studies of the Water-Gas Shift Reaction over Pt/Ce $\mathrm{Zr}_{1-\mathrm{x}} \mathrm{O}_{2}$ Catalysts: The Effect of Pt Particle Size and $\mathrm{Zr}$ Dopant, ACS Catalysis, 2 (2012) 2729-2742.

[7] D.A. Constantinou, M.C. Álvarez-Galván, J.L.G. Fierro, A.M. Efstathiou, Lowtemperature conversion of phenol into $\mathrm{CO}, \mathrm{CO}_{2}$ and $\mathrm{H}_{2}$ by steam reforming over La- 
containing supported Rh catalysts, Applied Catalysis B: Environmental, 117-118 (2012) 8195.

[8] K.C. Petallidou, C.M. Kalamaras, A.M. Efstathiou, The effect of $\mathrm{La}^{3+}, \mathrm{Ti}^{4+}$ and $\mathrm{Zr}^{4+}$ dopants on the mechanism of WGS on ceria-doped supported Pt catalysts, Catalysis Today, 228 (2014) 183-193.

[9] V. Recupero, L. Pino, M. Cordaro, A. Vita, F. Cipiti, M. Laganà, CO clean-up transient device integrated to a preferential oxidation reactor for PEFC electric vehicles, Fuel Processing Technology, 85 (2004) 1445-1452.

[10] A. Alihoseinzadeh, A.A. Khodadadi, Y. Mortazavi, Enhanced catalytic performance of $\mathrm{Au} / \mathrm{CuO}-\mathrm{ZnO}$ catalysts containing low $\mathrm{CuO}$ content for preferential oxidation of carbon monoxide in hydrogen-rich streams for PEMFC, International Journal of Hydrogen Energy, 39 (2014) 2056-2066.

[11] H. Arandiyan, Y. Wang, H. Sun, M. Rezaei, H. Dai, Ordered Meso- and Macroporous Perovskite Oxide Catalysts for Emerging Applications, Chemical Communications, (2018).

[12] J. Chen, H. Arandiyan, X. Gao, J. Li, Recent Advances in Catalysts for Methane Combustion, Catal. Surv. Asia, 19 (2015) 140-171.

[13] Y. Wang, H. Arandiyan, J. Scott, A. Bagheri, H. Dai, R. Amal, Recent advances in ordered meso/macroporous metal oxides for heterogeneous catalysis: a review, Journal of Materials Chemistry A, 5 (2017) 8825-8846.

[14] U.G. Singh, J. Li, J.W. Bennett, A.M. Rappe, R. Seshadri, S.L. Scott, A Pd-doped perovskite catalyst, , for CO oxidation, Journal of Catalysis, 249 (2007) 349-358.

[15] M. Rezaei, F. Meshkani, A.B. Ravandi, B. Nematollahi, A. Ranjbar, N. Hadian, Z. Mosayebi, Autothermal reforming of methane over Ni catalysts supported on nanocrystalline $\mathrm{MgO}$ with high surface area and plated-like shape, International Journal of Hydrogen Energy, 36 (2011) 11712-11717.

[16] Z. Alipour, M. Rezaei, F. Meshkani, Effects of support modifiers on the catalytic performance of $\mathrm{Ni} / \mathrm{Al}_{2} \mathrm{O}_{3}$ catalyst in $\mathrm{CO}_{2}$ reforming of methane, Fuel, 129 (2014) 197-203.

[17] M.M. Makri, M.A. Vasiliades, K.C. Petallidou, A.M. Efstathiou, Effect of support composition on the origin and reactivity of carbon formed during dry reforming of methane over 5wt\% Ni/Ce ${ }_{1-x} \mathrm{M}_{\mathrm{x}} \mathrm{O}_{2-\delta}\left(\mathrm{M}=\mathrm{Zr}^{4+}, \mathrm{Pr}^{3+}\right)$ catalysts, Catalysis Today, 259 (2016) 150-164.

[18] M.A. Vasiliades, M.M. Makri, P. Djinović, B. Erjavec, A. Pintar, A.M. Efstathiou, Dry reforming of methane over $5 \mathrm{wt} \% \mathrm{Ni} / \mathrm{Ce}_{1-\mathrm{x}} \mathrm{Pr}_{\mathrm{x}} \mathrm{O}_{2-\delta}$ catalysts: Performance and characterisation of active and inactive carbon by transient isotopic techniques, Applied Catalysis B: Environmental, 197 (2016) 168-183. 
[19] M.A. Vasiliades, P. Djinovic, A. Pintar, J. Kovac, A.M. Efstathiou, The effect of $\mathrm{CeO}_{2^{-}}$ $\mathrm{ZrO}_{2}$ structural differences on the origin and reactivity of carbon formed during methane dry reforming over $\mathrm{NiCo} / \mathrm{CeO}_{2}-\mathrm{ZrO}_{2}$ catalysts studied by transient techniques, Catalysis Science \& Technology, 7 (2017) 5422-5434.

[20] L.G. Tejuca, J.L.G. Fierro, J.M.D. Tascón, Structure and Reactivity of Perovskite-Type Oxides, in: H.P. D.D. Eley, B.W. Paul (Eds.) Advances in Catalysis, Academic Press1989, pp. 237-328.

[21] S.M. Lima, J.M. Assaf, M.A. Peña, J.L.G. Fierro, Structural features of $\mathrm{La}_{1-x} \mathrm{Ce}_{\mathrm{x}} \mathrm{NiO}_{3}$ mixed oxides and performance for the dry reforming of methane, Applied Catalysis A: General, 311 (2006) 94-104.

[22] H. Arai, T. Yamada, K. Eguchi, T. Seiyama, Catalytic combustion of methane over various perovskite-type oxides, Applied Catalysis, 26 (1986) 265-276.

[23] A. Khalesi, H.R. Arandiyan, M. Parvari, Production of Syngas by $\mathrm{CO}_{2}$ Reforming on $\mathrm{M}_{\mathrm{x}} \mathrm{La}_{1-\mathrm{x}} \mathrm{Ni}_{0.3} \mathrm{Al}_{0.7} \mathrm{O}_{3-\mathrm{d}}(\mathrm{M}=\mathrm{Li}, \mathrm{Na}, \mathrm{K})$ Catalysts, Ind. Eng. Chem. Res., 47 (2008) 5892-5898. [24] M. Parvary, S.H. Jazayeri, A. Taeb, C. Petit, A. Kiennemann, Promotion of active nickel catalysts in methane dry reforming reaction by aluminum addition, Catalysis Communications, 2 (2001) 357-362.

[25] H. Arandiyan, H. Dai, J. Deng, Y. Wang, H. Sun, S. Xie, B. Bai, Y. Liu, K. Ji, J. Li, Three-Dimensionally Ordered Macroporous $\mathrm{La}_{0.6} \mathrm{Sr}_{0.4} \mathrm{MnO}_{3}$ Supported Ag Nanoparticles for the Combustion of Methane, J. Phys. Chem. C, 118 (2014) 14913-14928.

[26] Y. Wang, H. Arandiyan, J. Scott, M. Akia, H. Dai, J. Deng, K.-F. Aguey-Zinsou, R. Amal, High Performance Au-Pd Supported on 3D Hybrid Strontium-Substituted Lanthanum Manganite Perovskite Catalyst for Methane Combustion, ACS Catal., 6 (2016) 6935-6947.

[27] Y. Wang, H. Arandiyan, H.A. Tahini, J. Scott, X. Tan, H. Dai, J.D. Gale, A.L. Rohl, S.C. Smith, R. Amal, The controlled disassembly of mesostructured perovskites as an avenue to fabricating high performance nanohybrid catalysts, Nature Communications, 8 (2017) 15553.

[28] H. Arandiyan, H. Chang, C. Liu, Y. Peng, J. Li, Dextrose-aided hydrothermal preparation with large surface area on $1 \mathrm{D}$ single-crystalline perovskite $\mathrm{La}_{0.5} \mathrm{Sr}_{0.5} \mathrm{CoO}_{3}$ nanowires without template: Highly catalytic activity for methane combustion, J. Mol. Catal. A: Chem., 378 (2013) 299-306.

[29] H. Arandiyan, J. Li, L. Ma, S.M. Hashemnejad, M.Z. Mirzaei, J. Chen, H. Chang, C. Liu, C. Wang, L. Chen, Methane reforming to syngas over $\mathrm{LaNi}_{\mathrm{x}} \mathrm{Fe}_{1-\mathrm{x}} \mathrm{O}_{3}$ mixed-oxide perovskites in the presence of $\mathrm{CO}_{2}$ and $\mathrm{O}_{2}$, Journal of Industrial and Engineering Chemistry, 18 (2012) 2103-2114. 
[30] H. Arandiyan, Y. Peng, C. Liu, H. Chang, J. Li, Effects of noble metals doped on mesoporous LaAlNi mixed oxide catalyst and identification of carbon deposit for reforming of $\mathrm{CH}_{4}$ with $\mathrm{CO}_{2}$, Journal of Chemical Technology \& Biotechnology, 89 (2014) 372-381.

[31] S.H. Xie, Y.X. Liu, J.G. Deng, J. Yang, X.T. Zhao, Z. Han, K.F. Zhang, Y. Wang, H. Arandiyan, H.X. Dai, Mesoporous CoO-supported palladium nanocatalysts with high performance for o-xylene combustion, Catalysis Science \& Technology, 8 (2018) 806-816.

[32] Y. Wang, H. Arandiyan, J. Scott, H. Dai, R. Amal, Hierarchically Porous Network-Like $\mathrm{Ni} / \mathrm{Co}_{3} \mathrm{O}_{4}$ : Noble Metal-Free Catalysts for Carbon Dioxide Methanation, Advanced Sustainable Systems, 2 (2018) 1700119.

[33] F. Liu, Y. Qu, Y. Yue, G. Liu, Y. Liu, Nano bimetallic alloy of Ni-Co obtained from $\mathrm{LaCo}_{\mathrm{x}} \mathrm{Ni}_{1-\mathrm{x}} \mathrm{O}_{3}$ and its catalytic performance for steam reforming of ethanol, RSC Advances, 5 (2015) 16837-16846.

[34] E.T. Saw, U. Oemar, X.R. Tan, Y. Du, A. Borgna, K. Hidajat, S. Kawi, Bimetallic Ni$\mathrm{Cu}$ catalyst supported on $\mathrm{CeO}_{2}$ for high-temperature water-gas shift reaction: Methane suppression via enhanced CO adsorption, Journal of Catalysis, 314 (2014) 32-46.

[35] L. Sun, K. Luo, J. Fan, Production of synthetic natural gas by CO methanation over $\mathrm{Ni} / \mathrm{Al}_{2} \mathrm{O}_{3}$ catalyst in fluidized bed reactor, Catal. Commun., 105 (2018) 37-42.

[36] X. Huo, Z. Wang, J. Huang, R. Zhang, Y. Fang, Bulk Mo and Co-Mo carbides as catalysts for methanation, Catal. Commun., 79 (2016) 39-44. 


\section{Graphical Abstract}

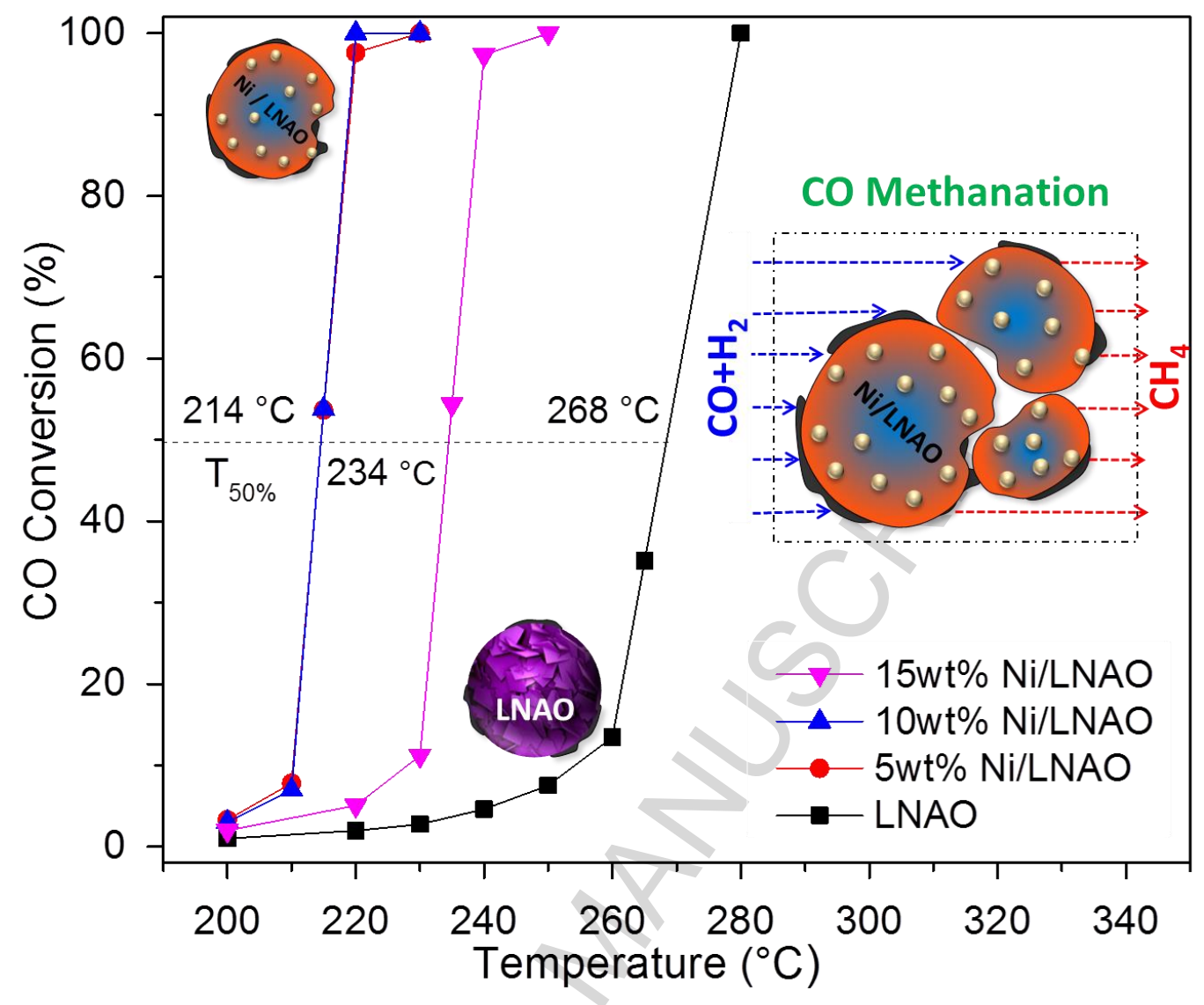




\section{Highlights}

- Flower-like LaNiAl complexes are self-assembled using the template-free strategy;

- LaNiAl-supported Ni catalysts are synthesized;

- The loading of Ni nanoparticles improves the catalytic activity for $\mathrm{CO}$ methanation;

- The $10 \mathrm{wt} \% \mathrm{Ni} / \mathrm{LaNiAl}$ catalyst shows an excellent activity in $\mathrm{CO}$ methanation. 